\title{
Regulatory Mechanisms of Somatostatin Expression
}

\author{
Emmanuel Ampofo *(1), Lisa Nalbach, Michael D. Menger and Matthias W. Laschke \\ Institute for Clinical \& Experimental Surgery, Saarland University, 66421 Homburg/Saar, Germany; \\ lisa.nalbach@uks.eu (L.N.); michael.menger@uks.eu (M.D.M.); matthias.laschke@uks.eu (M.W.L.) \\ * Correspondence: emmanuel.ampofo@uks.eu; Tel.: +49-6841-162-6561; Fax: +49-6841-162-6553
}

Received: 25 May 2020; Accepted: 9 June 2020; Published: 11 June 2020

\begin{abstract}
Somatostatin is a peptide hormone, which most commonly is produced by endocrine cells and the central nervous system. In mammals, somatostatin originates from pre-prosomatostatin and is processed to a shorter form, i.e., somatostatin-14, and a longer form, i.e., somatostatin-28. The two peptides repress growth hormone secretion and are involved in the regulation of glucagon and insulin synthesis in the pancreas. In recent years, the processing and secretion of somatostatin have been studied intensively. However, little attention has been paid to the regulatory mechanisms that control its expression. This review provides an up-to-date overview of these mechanisms. In particular, it focuses on the role of enhancers and silencers within the promoter region as well as on the binding of modulatory transcription factors to these elements. Moreover, it addresses extracellular factors, which trigger key signaling pathways, leading to an enhanced somatostatin expression in health and disease.
\end{abstract}

Keywords: somatostatin; pre-prosomatostatin; $\delta$-cells; central nervous system (CNS); gut; hypothalamus; cAMP resonse element (CRE); pancreas/duodenum homeobox protein (PDX)1; paired box protein (PAX)6; growth hormone $(\mathrm{GH})$; brain-derived neurotrophic factor (BDNF); glutamateric system; pancreas

\section{Introduction}

Somatostatin, also known as growth hormone-inhibiting hormone or somatotropin release-inhibiting factor, is a major product of the somatostatin gene [1]. The pre-mRNA contains an intron flanked by two exons [2]. After processing in the nucleus to produce mature mRNA, it is ordinarily degraded in the cytoplasm after several rounds of translation [3]. The biosynthesis of somatostatin is carried out via a 116-amino acid precursor protein, i.e., pre-prosomatostatin [4]. After removal of the 24-amino acid signal sequence, prosomatostatin, consisting of 92 amino acids, is formed. Prosomatostatin, in turn, is C-terminally processed to generate the cyclic peptides somatostatin-14 (SS-14) and somatostatin-28 (SS-28) [4]. Of interest, the two proteins were not identified in the same study. The isolation of SS-14 from bovine hypothalamic extracts was firstly reported in 1973 [1], while the N-terminally extended version SS-28 was described in 1980 [5]. To date, it is known that SS-14 is not only expressed in the hypothalamus but also in other parts of the central nervous system (CNS), in peripheral nerves and in pancreatic $\delta$-cells [6]. In contrast, SS-28 is the major final product in gastrointestinal D-cells [6]. In 2008, Samson et al. [7] identified a 13-amino acid peptide, which is also encoded by the somatostatin gene. This peptide, named neuronostatin, regulates neuronal function, blood pressure, and food intake [7]. Neuronostatin is highly expressed in the spleen, pancreas, cerebrum, and hypothalamus [8].

Both SS-14 and SS-28 are stored in secretory granules and their secretion is regulated by dietary components, such as amino acids, glucose, and fat [9-11], as well as by the adrenergic and muscarinic systems [12,13]. Both peptides exhibit a very short half-life $(\sim 1 \mathrm{~min})$ in the circulation [14]. It is estimated that $\sim 65 \%$ of the circulating somatostatin is secreted by gastrointestinal D-cells, $\sim 30 \%$ by 
the CNS and $\sim 5 \%$ by pancreatic $\delta$-cells [15-17]. The endocrine and paracrine signaling activity of somatostatin is mediated by its binding to specific somatostatin receptors (SSTRs), which belong to the class of G-protein-coupled receptors. Six different receptors (SSTR1, 2A and B, 3, 4, and 5) have been identified [18], which are widely expressed on various tissues, including retina and brain [19,20]. SS-14 binds with higher affinity to SSTRs 1-4, whereas SS-28 mainly interacts with SSTR5 [18]. After binding, SSTRs are phosphorylated, internalized into clathrin-coated vesicles, and addressed to endosomes. The receptors can then be either directly recycled to the plasma membrane or targeted by the proteasome pathway [21].

Under physiological conditions, somatostatin has a broad activity spectrum by regulating the complex balance of hormone release. For instance, it suppresses the release of growth hormone (GH), thyroid-stimulating hormone (TSH), and gastrointestinal hormones [16]. Moreover, somatostatin inhibits the secretion of insulin, glucagon, and pancreatic polypeptide from endocrine pancreatic cells [22,23] as well as the cytokine release from immune cells [24]. It also reduces the exocrine secretion of amylase of salivary glands as well as hydrochloric acid, pepsinogen, and intrinsic factor of the gastrointestinal mucosa $[25,26]$. Furthermore, somatostatin decreases portal pressure and retinal arteriolar and venular dilation $[27,28]$.

SSTRs are also expressed on pathological tissues, such as neuroendocrine tumors and solid organ tumors, including melanoma, prostate, and gastrointestinal cancers [29]. The binding of somatostatin to SSTR-expressing tumor cells leads to tumor regression by reducing cell proliferation and inducing apoptosis [30]. Moreover, somatostatin is capable of indirectly suppressing tumor growth by the inhibition of angiogenesis and modulation of the immune system [31]. However, the use of native somatostatin for therapeutic approaches is limited due to its short half-life [14]. To overcome this drawback, synthetic somatostatin analogs with a longer half-life have been developed [32]. Two of them, octreotide and lanreotide, are available for the treatment of neuroendocrine tumors that secrete excessive amounts of GH [33,34].

Both the secretory mechanism and the function of somatostatin are well described [15-17]. However, the mechanisms regulating somatostatin expression are less well known, although the peptide hormone was discovered almost 50 years ago. Pioneering work was done by the group of Goodman [35] and Dixon [36] during the 1980s. They characterized the somatostatin promoter region and regulatory elements. In the middle of the 1990s, Montminy et al. [37] summarized the known results about the regulation of somatostatin expression. Since then, many studies have reported novel mechanisms regulating the expression of the peptide hormone, and a review about the somatostatin expression is therefore timely. In this review, we provide an up-to-date overview of these mechanisms, taking into account the gene, promoter, and transcription factors, as well as important exogenous factors.

\section{The Somatostatin Gene}

In 1982, the group of Rutter was the first to describe the sequence of the human somatostatin cDNA out of the preprosomatostatin full-length mRNA [38]. Two years later, they published the sequence of the human somatostatin gene, which is localized on chromosome 3 [2]. The ortholog gene in rats is assigned to chromosome 11 and in mice to chromosome 16. The genomic landscapes of the three orthologues are partially similar and span a region of $\sim 1.6$ kilobases (Figure 1). In the following years, it has been shown that somatostatins are a structurally diverse family of peptide hormones in vertebrates [39]. Six somatostatin genes have been identified so far [39,40]. Somatostatin 1 is expressed in all vertebrates from agnathans to mammals and represents the ancestral gene of the family [39]. Somatostatin 2, also known as cortistatin, is specifically expressed in the brain but not in the pancreas or gut [41]. Somatostatin 1, somatostatin 2, and somatostatin 5 are thought to have been produced through the $1 \mathrm{R} / 2 \mathrm{R}$ whole-genome duplications early in vertebrate evolution [42]. Somatostatin 3 and somatostatin 6 would have been subsequently generated by tandem duplications of the somatostatin 1 as well as somatostatin 2 genes, respectively, at the base of the actinopterygian lineage [42]. In contrast, it is 
assumed that somatostatin 4 is derived from somatostatin 1, in teleost-specific 3R [42]. The physiological significance of somatostatin 1 is well established, whereas the different expression patterns of the other somatostatin genes might indicate that the genes have individually differing roles in various species [43]. For instance, sharks and other vertebrates show differential expression of somatostatin genes in different sets of brain neurons [44]. Gene duplication is thought to be a primary source for the evolution of novel functions [45]. In fact, it has been reported that cortistatin exerts different effects by partially antagonizing somatostatin 1 [41]. However, further studies are required to analyze whether genomic arrangements have any impact on somatostatin gene expression.

\section{Human somatostatin gene}

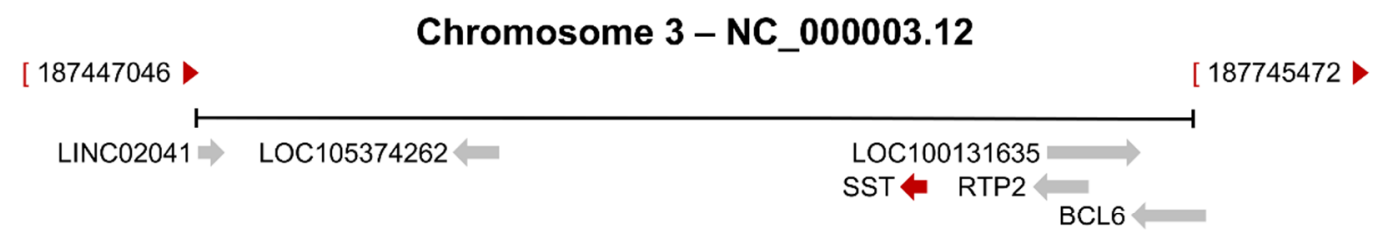

Mouse somatostatin gene

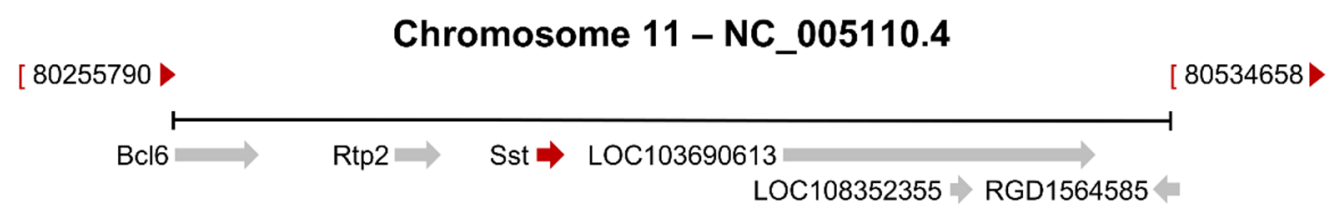

Rat somatostatin gene

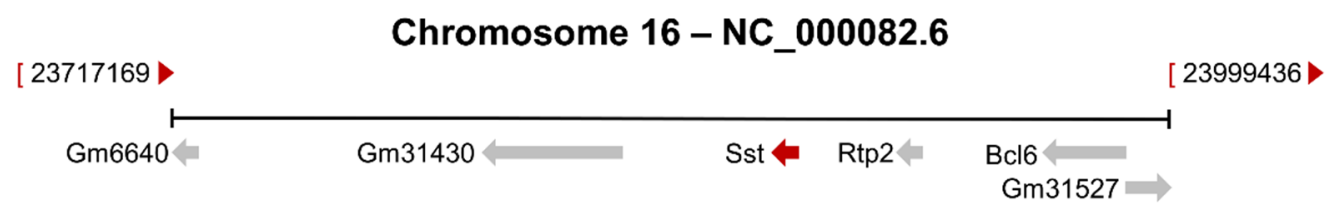

Figure 1. Genomic regions for the human somatostatin gene and the orthologue genes in rats and mice. Human somatostatin is located on chromosome 3, whereas mouse somatostatin is located on chromosome 11 and rat somatostatin on chromosome 16. Genomic contexts are conserved in the three species regarding the receptor transporter protein (RTP)2.

\section{The Somatostatin Promoter}

Promoters are ignition systems of genes and harbor various elements, such as enhancers and silencers, which regulate the transcriptional activation [46]. The promoter regions of the most common secretory proteins, such as insulin [47], glucagon [48], or leptin [49], are well characterized. Although somatostatin was discovered a long time ago and the mode of action of the peptide hormone is well understood, relatively little is known about the promoter region of the gene. Montminy et al. [35] were the first to identify a regulatory element in the promoter region of the rat somatostatin gene. They transfected PC12 cells with deletion mutants of a 750-bp region in $5^{\prime}$ to the somatostatin transcriptional start and identified a cAMP response element (CRE) with the consensus sequence 'TGACGTCA' [35]. This sequence resides between the nucleotides -58 and -35 upstream of the transcriptional initiation site and is crucially involved in tissue-specific somatostatin gene expression, because its mutation results in a significant loss of transcriptional activity (Figure 2) [36,50]. This is also the reason why the CRE of the somatostatin promoter is still used as a prototype to study cAMP-dependent mechanisms. 


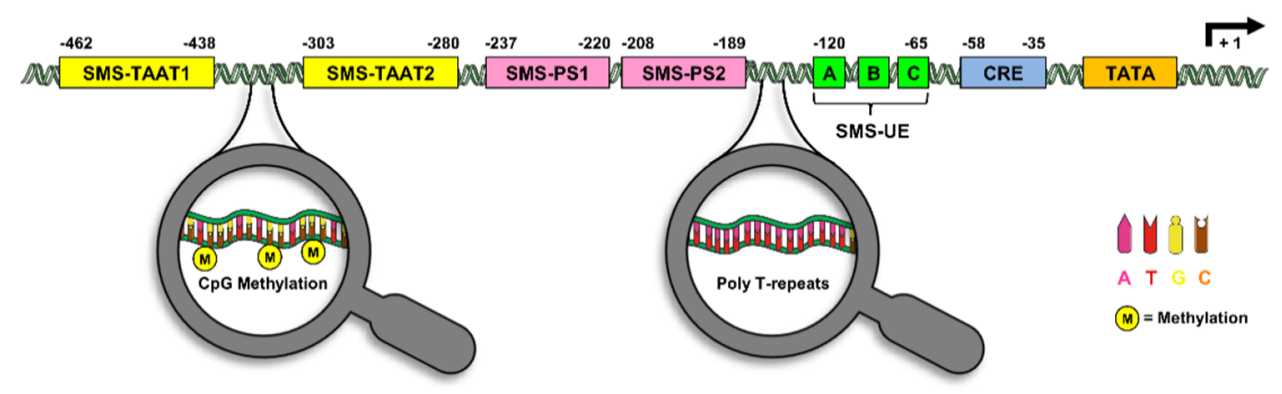

Figure 2. Regulatory elements of the rat somatostatin promoter. The somatostatin promoter harbors a complex arrangement of multiple regulatory elements, such as cAMP response element (CRE), specific upstream-enhancer elements (SMS-UE, SMS-TAAT1, and SMS-TAAT2) interspersed with the proximal silencer elements (SMS-PS1 and SMS-PS2) upstream of the TATA box. Moreover, additional methylation sites, i.e., $\mathrm{GpC}$ islets and poly-T repeats, are found in the somatostatin promoter region.

A specific upstream-enhancer element (SMS-UE), adjacent to the CRE, was first in detected in $\delta$-cells [51]. The SMS-UE is located between the nucleotides -120 and -65 and positively regulates somatostatin gene expression synergistically with the CRE under both basal and cAMP-induced conditions [51]. Further detailed analyses revealed that SMS-UE is a tripartite element, which includes the domains A, B, and C (Figure 2) [52]. Domain A binds a ubiquitous protein with characteristics similar to the CCAAT box-binding protein CBF. Domain B harbors an insulin gene enhancer protein (Isl)-1-like binding site. Domain C contains a pancreatic islet cell enhancer sequence (PISCES) motif [52], which is found in the promoter element of the glucagon and insulin gene [53,54]. The two additional activator regions SMS-TAAT1 ( -462 to -438 ) and SMS-TAAT2 (-303 to -280$)$ were detected upstream of SMS-UE, which seem to be required for pancreatic somatostatin expression [55]. In contrast, Valleja et al. [56] detected the two silencer elements SMS-PS1 and SMS-PS2 resided between -250 and -120 upstream of the gene (Figure 2). These elements are not cell specific, because they are capable of reducing somatostatin gene transcription in somatostatin-producing as well as non-producing cells [56].

Beside silencer elements, the methylation of CG dinucleotides, also known as CpG islands, within promoter regions represents a common mechanism for gene inactivation [57-59]. In this context, it has been reported that somatostatin mRNA levels were significantly lower in the tissue of gastric cancer when compared to non-tumor tissue [60,61]. Additional analyses revealed that this is due to a somatostatin promoter hypermethylation, indicating that epigenetic modification of the promoter may be a crucial factor for gastrointestinal tract carcinogenesis $[60,61]$. In fact, the reduced somatostatin production due to epigenetically regulated promoter hypermethylation contributes to the uncontrolled cell proliferation in colon cancer cells, because octreotide treatment significantly attenuates cell death and cell proliferation [62]. However, whether promoter methylation also regulates physiological somatostatin expression in gastrointestinal D-cells, the CNS, or pancreatic $\delta$-cells has still to be clarified.

Polymorphisms within promoter regions may also affect the expression of various genes and, thus, constitute common sources of phenotypic variation and susceptibility to common diseases [63]. Tremblay et al. [64] identified a poly-T repeat sequence in the somatostatin promoter ranging from 12 to $17 \mathrm{~T}$. Of interest, the length of this poly-T repeat affects arterial blood pressure levels and is associated with the risk of hypertension, especially among obese individuals [64]. In a follow-up study, the authors found that the poly-T repeat polymorphism is also associated with the expression of metabolic syndrome components, indicating that this genetic alteration may induce somatostatin gene expression [65]. In fact, $\mathrm{Li}$ et al. [66] reported that elevated levels of somatostatin are involved in the progression of high-fat diet-induced metabolic syndrome. However, further detailed promoter analyses are required to assess the effect of polymorphisms on somatostatin gene expression. 


\section{Transcription Factors Regulating Somatostatin Expression}

The expression of somatostatin is restricted to distinct tissues, indicating that cell-specific determinants control the transcription of this peptide hormone. Montminy and Bilezikjian [67] demonstrated that the transcription factor cAMP response element-binding protein (CREB) induced by the cAMP-dependent pathway binds to a promoter sequence that includes the CRE. In the following years, the binding of CREB to the consensus site TGACGTCA was verified $[68,69]$. Under physiological conditions, CREB is expressed in all nucleated cells and the loss of this transcription factor leads to embryonal and neuronal deficits associated with a reduced lifespan [70,71]. This clearly indicates that CREB is essential for major cellular functions. The paradigm that CREB is a crucial activator of somatostatin expression was supported by the work of Walton et al. [72]. They generated a CREB mutant (KCREB), which forms inactive heterodimers with CREB, resulting in repressed somatostatin transcription [72]. However, CREB binding does not appear to be solely responsible for the expression of somatostatin. CREB is phosphorylated by protein kinase A (PKA) on serine 133 after stimulation of the cAMP pathway [73]. This, in turn, induces the binding of the CREB-binding protein (CBP) to the transactivation domain of CREB, which further enhances somatostatin transcription $[37,74]$. Accordingly, the inhibition of PKA represses CREB-mediated somatostatin gene expression [75]. Beside these findings, Gachon et al. [76] detected a complex consisting of transcription activator Tax and CREB-2, also known as activating transcription factor (ATF)-4, on CRE of the somatostatin promoter. Of note, bound CREB-2 was not phosphorylated within this complex [76]. Thus, the recruitment of Tax to non-phosphorylated CREB-2 may allow the stimulation of somatostatin transcription independent of the phospho-regulated pathways.

The transcription factor pancreas/duodenum homeobox protein (PDX)1, formerly known as islet/duodenum homeobox (IDX)-1 or somatostatin transactivating factor (STF)-1, is another regulator of somatostatin gene expression. PDX1 triggers insulin gene expression in $\beta$-cells [77] and is essential for pancreas development, most probably by determining the maturation and differentiation of common pancreatic precursor cells in the developing gut [78]. In $\delta$-cells, PDX1 is expressed at a low level [79] and activates somatostatin transcription by binding to regulatory elements in the $5^{\prime}$ flanking region of the rat somatostatin gene $[55,80]$. Further analyses revealed that PDX1 stimulates somatostatin transcription via binding to SMS-TAAT2, because mutations in this element attenuate its transactivation $[55,81]$. Somatostatin expression is also induced by $\mathrm{Pbx}$, a transcription factor belonging to the TALE class homeobox family. Pbx is capable of forming a heterodimer with PDX1, which induces somatostatin transcription by binding to SMS-TAAT1 and SMS-UE [82]. In addition, Pbx can form heterodimers with Prep1, an additional TALE class homeobox member. However, this complex triggers somatostatin gene expression solely by binding to SMS-UE [83].

The transcription factor paired box protein (PAX) 6 is expressed in several different embryonic tissues as well as in distinct adult tissues, such as pancreatic islet cells. The complex tissue-specific PAX6-induced gene expression is made possible by several functional domains that facilitate DNA binding and protein-protein interactions [84]. It has been reported that the binding of PAX6 to the PISCES motif within endocrine gene promoters crucially regulates their gene expression [53]. For instance, Pax6 prevents the activation of insulin gene expression by occupying the PDX1 binding site in $\beta$-cells [85]. In contrast, PAX6-induced glucagon gene expression is diminished by exogenous PDX1 in $\alpha$-cells [86]. The PISCES motif within the somatostatin promoter is localized in the domain $\mathrm{C}$ of SMS-UE [52]. Of note, PAX6 as well as PDX1 bind to completely overlapping sequences within this domain [87]. Moreover, the phosphorylation of PAX6 on serine 313 and serine 398 by extracellular signal-related kinase (ERK) is required for PAX6-mediated somatostatin transcription [74]. This indicates that beside the PKA-CREB axis, the ERK-PAX6 axis also contributes to the cell specificity of somatostatin expression.

Activin, a member of the transforming growth factor $\beta$ (TGF $\beta$ ) superfamily, is capable of decreasing cell proliferation in a variety of cell types [88]. The functions of activin are mediated by activin-like kinase (ALK) receptor, of which ALK4 is the main receptor mediating activin signaling in human 
cells [88]. Mice lacking the ALK4 receptor in GABAergic interneurons exhibit substantial deficits in medial ganglionic eminence (MGE)-derived somatostatin-expressing interneurons, which represent $\sim 30 \%$ of all cortical GABAergic interneurons $[89,90]$. The development of these cells is controlled by various transcription factors, including SATB1 [91]. Recently, Göngrich et al. [89] demonstrated that SATB1 binds to different regions of the PISCES motif within the somatostatin promoter and that the activin signal alters this interaction from decreased binding to the distal region to increased binding to the more proximal region. Of note, activin does not increase somatostatin transcription, indicating that activin signaling is insufficient to regulate the expression of the peptide hormone. However, activin signaling may trigger somatostatin gene expression by reorganization of its gene locus.

\section{Exogenous Factors Regulating Somatostatin Expression}

The regulation of transcription factor activity is quite a complex process and involves post-translational modification, protein-protein interactions, as well as regulation through specific molecules, also known as ligands. These processes are mainly triggered by extracellular factors, leading to multiple intracellular signaling transductions [92]. Rage et al. [93] reported an increased somatostatin gene expression in primary hypothalamic neurons that were exposed to glutamate. In contrast, gamma-aminobutyric acid (GABA) reduces somatostatin gene expression via binding to $\mathrm{GABA}_{\mathrm{A}}$ receptors $[94,95]$. The regulation of somatostatin expression by the GABAergic and glutamatergic system has important physiological functions, because this peptide impedes principal neurons from over-reacting by reducing their excitability and, thus, damping the rate of fire [96].

Somatostatin expression is further mediated by membrane depolarization $[97,98]$. It has been shown that cerebrocortical cells exposed to high $\mathrm{K}^{+}$concentrations not only induce somatostatin release but also trigger its gene expression $[99,100]$. Of interest, this process requires the activation of $\mathrm{Ca}^{2+}$ channels, whereas $\mathrm{Na}^{+}$channel blockade has no effect on $\mathrm{K}^{+}$-induced somatostatin expression $[99,101]$. Additional gene regulatory analyses revealed that $\mathrm{K}^{+}$exposition stimulates the calmodulin/cAMP/PKA pathway, resulting in CREB-dependent somatostatin gene expression [102].

Ehrman et al. [103] detected increased somatostatin mRNA levels in islets of rainbow trout, which were cultivated under high-glucose conditions. This indicates for the first time that glucose not only regulates somatostatin release but also somatostatin biosynthesis $[103,104]$. In a follow up study, the authors could show that somatostatin expression is dependent on glucose-mediated hormone secretion [105]. They detected insulin-stimulated somatostatin expression only in the presence of low glucose, whereas glucagon-stimulated somatostatin expression occurred under high glucose concentrations [105]. It should be noted that the authors analyzed somatostatin $3^{\prime}$ and $3^{\prime \prime}$ in their study, which are not the fish counterparts of somatostatin in mammals. However, there are several indications that the expression of somatostatin seems to also be regulated by glucose in mammals. In fact, somatostatin mRNA levels were significantly increased in diabetic rats [106,107], with a return to control levels during insulin treatment $[106,108]$. Therefore, it is tempting to speculate that signal elements of the glucose/insulin cascades may influence CREB- or PDX1-dependent somatostatin expression.

The secretion of GH is modulated by two hypothalamic hormones, GHRH and somatostatin. Interestingly, hypoglycemia inhibits the release of GH in male rats, which is caused by a secretion of hypothalamic somatostatin [109]. Further detailed analyses revealed that insulin-induced hypoglycemia not only increased hypothalamic somatostatin release but also its gene expression in rats [110]. However, this is in contrast to the situation in humans, where hypoglycemia stimulates GH release, and the administration of glucose suppresses GH secretion [111,112]. Further studies are therefore needed to analyze whether glucose regulates hypothalamic somatostatin secretion or gene expression in humans.

Brain-derived neurotrophic factor (BDNF) belongs to the class of neurotrophins and is highly expressed in the hypothalamus of rats [113]. BDNF signaling is primarily mediated by its affinity to the tropomyosin receptor kinase B (TrkB) [114]. TrkB activation, in turn, induces three major intracellular signaling pathways, including mitogen-activated protein kinase (MAPK), phosphatidylinositol-3-kinase (PI3K), and phospholipase C (PLC) $\gamma$ [115]. Rage et al. [116] found that BNDF activates somatostatin 
gene expression in hypothalamic neurons, which was mediated by rapid activation of ERK1/2 and Akt kinases, resulting in the phosphorylation of CREB [117]. BDNF also enhances the activation of calcium-calmodulin-dependent kinases (CAMKs) [118]. Of interest, activated CAMK IV phosphorylates CBP at serine 301, which enhances CBP-dependent CREB transcription [119]. Hence, the suppression of CAMK activity reduces the somatostatin mRNA level [117]. Furthermore, BNDF upregulates the level of the vasoactive intestinal polypeptide (VIP), which has been shown to trigger somatostatin gene expression [120]. These findings clearly indicate that BNDF is a crucial regulator of somatostatin expression. Indeed, this factor significantly controls neuronal survival at the early stages of brain development by inducing somatostatin gene expression via different signaling pathways.

\section{Putative Autocrine Feedback}

Autocrine feedback loops are mechanisms that allow cytokines or hormones to modulate the mode of action of their own cell. Although these mechanisms are not widespread, some have already been identified in detail [121-123]. For instance, autocrine GH increases cell survival, proliferation, and motility, as well as decreases cell apoptosis in GH-secreting breast adenocarcinoma cells [124]. Glucagon, secreted by pancreatic $\alpha$-cells, even upregulates its own gene expression by binding to the glucagon receptor, which leads to activated PKA-dependent signaling pathways [125]. It is not known whether somatostatin is also able to regulate its own expression, but there are some indications that this might be possible. The binding of somatostatin to SSTR5 mediates an inhibitory effect on islet cell survival and insulin expression [126,127]. Zhou et al. [128] reported that SSTR5-induced signaling is linked to PDX1. They found, that treatment of insulinoma cells with a SSTR5 agonist reduces glucose-stimulated insulin secretion due to diminished PDX1 expression. Of interest, PDX1 has been shown to increase somatostatin expression [55,81]. This is in line with recent findings demonstrating that antagonizing SSTR5 increases glucagon like peptide-1 as well as somatostatin secretion from the perfused proximal small intestine in mice [129]. Therefore, it is tempting to speculate that somatostatin is capable of regulating its expression by a negative feedback loop via SSTR5.

Adenylyl cyclase (AC) catalyzes the conversion of ATP to cAMP, which, in turn, activates PKA [130]. It has been reported that SSTR signaling pathways efficiently inhibit AC via coupling to $G_{i}$ proteins [131]. This leads to a decreased cellular cAMP level, which reduces pituitary hormone secretion and may also contribute to the antiproliferative effects of somatostatin [132-134]. The expression of somatostatin itself is, as already stated, induced by cAMP via the PKA-CREB-axis, hence reduced AC activity after SSTR activation may repress somatostatin expression. However, detailed studies are now required to determine whether somatostatin affects its own expression.

\section{Conclusions}

The understanding of the regulatory mechanisms of somatostatin expression has markedly increased over the past decades. In addition to the known post-translational mechanisms, i.e., proteolytic cleavage of pre-prosomatostatin and somatostatin secretion, it has been shown that different pretranslational mechanisms, such as modifications of the promoter by methylations and polymorphisms as well as the regulation of transcription factor activity, are required for regulation of the cellular somatostatin content (Figure 3). Future studies now have to clarify whether additional factors and mechanisms are involved in the regulation of somatostatin expression. These may include miRNAs, which play an important role in the fine-tuning of protein expression [135], the process of alternative splicing [136] as well as post-translational protein modifications, such as phosphorylation and sumoylation [137] (Figure 3). 


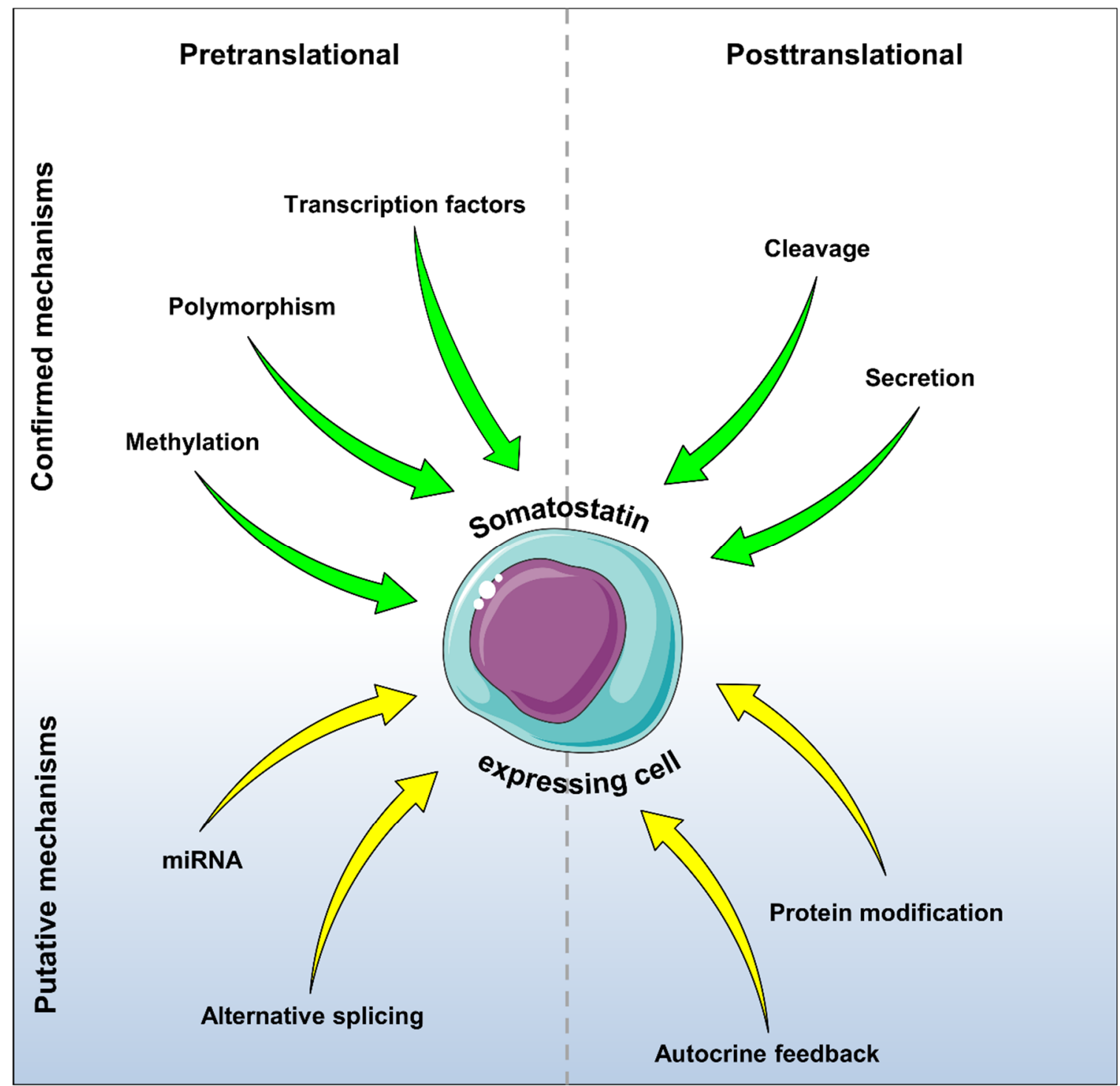

Figure 3. The regulatory mechanisms of somatostatin expression. It is known that the cellular somatostatin content is pretranslationally regulated by methylations and polymorphisms within the promoter region as well as by the activity of different transcription factors (green arrows). On the posttranslational level, the cellular somatostatin content is regulated by proteolytic cleavage of pre-prosomatostatin into somatostatin (SS-14 and SS-28) and by secretion (green arrows). Further putative factors and mechanisms, which may regulate the expression of the peptide hormone, are miRNAs, alternative splicing, autocrine feedback, and protein modification (yellow arrows).

Funding: We acknowledge support by the Deutsche Forschungsgemeinschaft (DFG, German Research Foundation) and Saarland University within the funding programme Open Access Publishing.

Acknowledgments: The authors thank Servier Medical Art for providing access to designed medical elements (https://smart.servier.com/), supporting the generation of graphical items in this publication.

Conflicts of Interest: The authors declare no conflict of interest.

\section{References}

1. Brazeau, P.; Vale, W.; Burgus, R.; Ling, N.; Butcher, M.; Rivier, J.; Guillemin, R. Hypothalamic polypeptide that inhibits the secretion of immunoreactive pituitary growth hormone. Science 1973, 179, 77-79. [CrossRef]

2. Shen, L.P.; Rutter, W.J. Sequence of the human somatostatin I gene. Science 1984, 224, 168-171. [CrossRef] 
3. Cote, G.J.; Gagel, R.F. Different mechanisms of calcitonin, calcitonin gene-related peptide, and somatostatin regulation by glucocorticoids in a cell culture of human medullary thyroid carcinoma. Henry Ford Hosp. Med. J. 1987, 35, 149-152. [PubMed]

4. Warren, T.G.; Shields, D. Expression of preprosomatostatin in heterologous cells: Biosynthesis, posttranslational processing, and secretion of mature somatostatin. Cell 1984, 39, 547-555. [CrossRef]

5. Pradayrol, L.; Jornvall, H.; Mutt, V.; Ribet, A. N-terminally extended somatostatin: The primary structure of somatostatin-28. FEBS Lett. 1980, 109, 55-58. [CrossRef]

6. Francis, B.H.; Baskin, D.G.; Saunders, D.R.; Ensinck, J.W. Distribution of somatostatin-14 and somatostatin-28 gastrointestinal-pancreatic cells of rats and humans. Gastroenterology 1990, 99, 1283-1291. [CrossRef]

7. Samson, W.K.; Zhang, J.V.; Avsian-Kretchmer, O.; Cui, K.; Yosten, G.L.; Klein, C.; Lyu, R.M.; Wang, Y.X.; Chen, X.Q.; Yang, J.; et al. Neuronostatin encoded by the somatostatin gene regulates neuronal, cardiovascular, and metabolic functions. J. Biol. Chem. 2008, 283, 31949-31959. [CrossRef]

8. Vainio, L.; Perjes, A.; Ryti, N.; Magga, J.; Alakoski, T.; Serpi, R.; Kaikkonen, L.; Piuhola, J.; Szokodi, I.; Ruskoaho, H.; et al. Neuronostatin, a novel peptide encoded by somatostatin gene, regulates cardiac contractile function and cardiomyocyte survival. J. Biol. Chem. 2012, 287, 4572-4580. [CrossRef] [PubMed]

9. DiGruccio, M.R.; Mawla, A.M.; Donaldson, C.J.; Noguchi, G.M.; Vaughan, J.; Cowing-Zitron, C.; van der Meulen, T.; Huising, M.O. Comprehensive alpha, beta and delta cell transcriptomes reveal that ghrelin selectively activates delta cells and promotes somatostatin release from pancreatic islets. Mol. Metab. 2016, 5, 449-458. [CrossRef] [PubMed]

10. Olofsson, C.S.; Salehi, A.; Gopel, S.O.; Holm, C.; Rorsman, P. Palmitate stimulation of glucagon secretion in mouse pancreatic alpha-cells results from activation of L-type calcium channels and elevation of cytoplasmic calcium. Diabetes 2004, 53, 2836-2843. [CrossRef]

11. Ipp, E.; Dobbs, R.E.; Arimura, A.; Vale, W.; Harris, V.; Unger, R.H. Release of immunoreactive somatostatin from the pancreas in response to glucose, amino acids, pancreozymin-cholecystokinin, and tolbutamide. J. Clin. Investig. 1977, 60, 760-765. [CrossRef] [PubMed]

12. Ahren, B.; Paquette, T.L.; Taborsky, G.J., Jr. Effect and mechanism of vagal nerve stimulation on somatostatin secretion in dogs. Am. J. Physiol. 1986, 250, E212-E217. [CrossRef] [PubMed]

13. Hokfelt, T.; Elfvin, L.G.; Elde, R.; Schultzberg, M.; Goldstein, M.; Luft, R. Occurrence of somatostatin-like immunoreactivity in some peripheral sympathetic noradrenergic neurons. Proc. Natl. Acad. Sci. USA 1977, 74, 3587-3591. [CrossRef]

14. Patel, Y.C.; Wheatley, T. In vivo and in vitro plasma disappearance and metabolism of somatostatin-28 and somatostatin-14 in the rat. Endocrinology 1983, 112, 220-225. [CrossRef] [PubMed]

15. Rorsman, P.; Huising, M.O. The somatostatin-secreting pancreatic delta-cell in health and disease. Nat. Rev. Endocrinol. 2018, 14, 404-414. [CrossRef]

16. Frohman, L.A.; Downs, T.R.; Kelijman, M.; Clarke, I.J.; Thomas, G. Somatostatin secretion and action in the regulation of growth hormone secretion. Metabolism 1990, 39, 43-45. [CrossRef]

17. Saiz-Sanchez, D.; Ubeda-Banon, I.; Flores-Cuadrado, A.; Gonzalez-Rodriguez, M.; Villar-Conde, S.; Astillero-Lopez, V.; Martinez-Marcos, A. Somatostatin, Olfaction, and Neurodegeneration. Front. Neurosci. 2020, 14, 96. [CrossRef]

18. Patel, Y.C.; Greenwood, M.T.; Warszynska, A.; Panetta, R.; Srikant, C.B. All five cloned human somatostatin receptors (hSSTR1-5) are functionally coupled to adenylyl cyclase. Biochem. Biophys. Res. Commun. 1994, 198, 605-612. [CrossRef]

19. Kossut, M.; Lukomska, A.; Dobrzanski, G.; Liguz-Lecznar, M. Somatostatin receptors in the brain. Postepy Biochem. 2018, 64, 213-221. [CrossRef]

20. Klisovic, D.D.; O’Dorisio, M.S.; Katz, S.E.; Sall, J.W.; Balster, D.; O’Dorisio, T.M.; Craig, E.; Lubow, M. Somatostatin receptor gene expression in human ocular tissues: RT-PCR and immunohistochemical study. Investig. Ophthalmol. Vis. Sci. 2001, 42, 2193-2201.

21. Csaba, Z.; Peineau, S.; Dournaud, P. Molecular mechanisms of somatostatin receptor trafficking. J. Mol. Endocrinol. 2012, 48, R1-R12. [CrossRef]

22. Koerker, D.J.; Ruch, W.; Chideckel, E.; Palmer, J.; Goodner, C.J.; Ensinck, J.; Gale, C.C. Somatostatin: Hypothalamic inhibitor of the endocrine pancreas. Science 1974, 184, 482-484. [CrossRef] [PubMed] 
23. Strowski, M.Z.; Parmar, R.M.; Blake, A.D.; Schaeffer, J.M. Somatostatin inhibits insulin and glucagon secretion via two receptors subtypes: An in vitro study of pancreatic islets from somatostatin receptor 2 knockout mice. Endocrinology 2000, 141, 111-117. [CrossRef]

24. Van Hagen, P.M.; Krenning, E.P.; Kwekkeboom, D.J.; Reubi, J.C.; Anker-Lugtenburg, P.J.; Lowenberg, B.; Lamberts, S.W. Somatostatin and the immune and haematopoetic system; A review. Eur. J. Clin. Investig. 1994, 24, 91-99. [CrossRef] [PubMed]

25. Tanaka, T.; Tani, S. Inhibitory action of somatostatin on cAMP dependent pepsinogen secretion from rat gastric chief cells: Involvement of pertussis toxin-sensitive G-protein. Biol. Pharm. Bull. 1994, 17, 415-418. [CrossRef]

26. Oddsdottir, M.; Ballantyne, G.H.; Adrian, T.E.; Zdon, M.J.; Zucker, K.A.; Modlin, I.M. Somatostatin inhibition of intrinsic factor secretion from isolated guinea pig gastric glands. Scand. J. Gastroenterol. 1987, 22, 233-238. [CrossRef]

27. Grauslund, J.; Frydkjaer-Olsen, U.; Peto, T.; Fernandez-Carneado, J.; Ponsati, B.; Hernandez, C.; Cunha-Vaz, J.; Simo, R. Topical Treatment With Brimonidine and Somatostatin Causes Retinal Vascular Dilation in Patients With Early Diabetic Retinopathy From the EUROCONDOR. Investig. Ophthalmol. Vis. Sci. 2019, 60, 2257-2262. [CrossRef]

28. Zhang, C.; Xu, J.M.; Kong, D.R.; Min, X.K.; Chen, R. Immediate effects of different schedules of somatostatin on portal pressure in patients with liver cirrhosis. J. Clin. Pharm. Ther. 2013, 38, 206-211. [CrossRef]

29. Ruscica, M.; Arvigo, M.; Steffani, L.; Ferone, D.; Magni, P. Somatostatin, somatostatin analogs and somatostatin receptor dynamics in the biology of cancer progression. Curr. Mol. Med. 2013, 13, 555-571. [CrossRef]

30. Barbieri, F.; Bajetto, A.; Pattarozzi, A.; Gatti, M.; Wurth, R.; Thellung, S.; Corsaro, A.; Villa, V.; Nizzari, M.; Florio, T. Peptide receptor targeting in cancer: The somatostatin paradigm. Int. J. Pept. 2013, 2013, 926295. [CrossRef]

31. Theodoropoulou, M.; Stalla, G.K. Somatostatin receptors: From signaling to clinical practice. Front. Neuroendocrinol. 2013, 34, 228-252. [CrossRef] [PubMed]

32. Gomes-Porras, M.; Cardenas-Salas, J.; Alvarez-Escola, C. Somatostatin Analogs in Clinical Practice: A Review. Int. J. Mol. Sci. 2020, 21, 1682. [CrossRef]

33. Godara, A.; Siddiqui, N.S.; Byrne, M.M.; Saif, M.W. The safety of lanreotide for neuroendocrine tumor. Expert Opin. Drug Saf. 2019, 18, 1-10. [CrossRef] [PubMed]

34. Yau, H.; Kinaan, M.; Quinn, S.L.; Moraitis, A.G. Octreotide long-acting repeatable in the treatment of neuroendocrine tumors: Patient selection and perspectives. Biol. Targets Ther. 2017, 11, 115-122. [CrossRef] [PubMed]

35. Montminy, M.R.; Sevarino, K.A.; Wagner,J.A.; Mandel, G.; Goodman, R.H. Identification of a cyclic-AMP-responsive element within the rat somatostatin gene. Proc. Natl. Acad. Sci. USA 1986, 83, 6682-6686. [CrossRef]

36. Andrisani, O.M.; Hayes, T.E.; Roos, B.; Dixon, J.E. Identification of the promoter sequences involved in the cell specific expression of the rat somatostatin gene. Nucleic Acids Res. 1987, 15, 5715-5728. [CrossRef]

37. Montminy, M.; Brindle, P.; Arias, J.; Ferreri, K.; Armstrong, R. Regulation of somatostatin gene transcription by cAMP. Adv. Pharmacol. 1996, 36, 1-13.

38. Shen, L.P.; Pictet, R.L.; Rutter, W.J. Human somatostatin I: Sequence of the cDNA. Proc. Natl. Acad. Sci. USA 1982, 79, 4575-4579. [CrossRef]

39. Tostivint, H.; Lihrmann, I.; Vaudry, H. New insight into the molecular evolution of the somatostatin family. Mol. Cell. Endocrinol. 2008, 286, 5-17. [CrossRef]

40. Liu, Y.; Lu, D.; Zhang, Y.; Li, S.; Liu, X.; Lin, H. The evolution of somatostatin in vertebrates. Gene 2010, 463, 21-28. [CrossRef]

41. De Lecea, L. Cortistatin: A natural somatostatin analog. J. Endocrinol. Investig. 2005, 28, 10-14.

42. Tostivint, H.; Gaillard, A.L.; Mazan, S.; Pezeron, G. Revisiting the evolution of the somatostatin family: Already five genes in the gnathostome ancestor. Gen. Comp. Endocrinol. 2019, 279, 139-147. [CrossRef] [PubMed]

43. Sui, C.; Chen, J.; Ma, J.; Zhao, W.; Canário, A.V.M.; Martins, R.S.T. Somatostatin 4 regulates growth and modulates gametogenesis in zebrafish. Aquac. Fish. 2019, 4, 239-246. [CrossRef]

44. Sobrido-Camean, D.; Tostivint, H.; Mazan, S.; Rodicio, M.C.; Rodriguez-Moldes, I.; Candal, E.; Anadon, R.; Barreiro-Iglesias, A. Differential expression of five prosomatostatin genes in the central nervous system of the catshark Scyliorhinus canicula. J. Comp. Neurol. 2020. [CrossRef] [PubMed] 
45. Magadum, S.; Banerjee, U.; Murugan, P.; Gangapur, D.; Ravikesavan, R. Gene duplication as a major force in evolution. J. Genet. 2013, 92, 155-161. [CrossRef] [PubMed]

46. Ayoubi, T.A.; Van De Ven, W.J. Regulation of gene expression by alternative promoters. FASEB J. 1996, 10, 453-460. [CrossRef]

47. Ohneda, K.; Mirmira, R.G.; Wang, J.; Johnson, J.D.; German, M.S. The homeodomain of PDX-1 mediates multiple protein-protein interactions in the formation of a transcriptional activation complex on the insulin promoter. Mol. Cell Biol. 2000, 20, 900-911. [CrossRef]

48. Gosmain, Y.; Cheyssac, C.; Heddad Masson, M.; Dibner, C.; Philippe, J. Glucagon gene expression in the endocrine pancreas: The role of the transcription factor Pax6 in alpha-cell differentiation, glucagon biosynthesis and secretion. Diabetes Obes. Metab. 2011, 13 (Suppl. 1), 31-38. [CrossRef]

49. Fukuda, H.; Iritani, N. Transcriptional regulation of leptin gene promoter in rat. FEBS Lett. 1999, 455, 165-169. [CrossRef]

50. Powers, A.C.; Tedeschi, F.; Wright, K.E.; Chan, J.S.; Habener, J.F. Somatostatin gene expression in pancreatic islet cells is directed by cell-specific DNA control elements and DNA-binding proteins. J. Biol. Chem. 1989, 264, 10048-10056.

51. Vallejo, M.; Miller, C.P.; Habener, J.F. Somatostatin gene transcription regulated by a bipartite pancreatic islet D-cell-specific enhancer coupled synergetically to a cAMP response element. J. Biol. Chem. 1992, 267, 12868-12875. [PubMed]

52. Vallejo, M.; Penchuk, L.; Habener, J.F. Somatostatin gene upstream enhancer element activated by a protein complex consisting of CREB, Isl-1-like, and alpha-CBF-like transcription factors. J. Biol. Chem. 1992, 267, 12876-12884. [PubMed]

53. Beimesche, S.; Neubauer, A.; Herzig, S.; Grzeskowiak, R.; Diedrich, T.; Cierny, I.; Scholz, D.; Alejel, T.; Knepel, W. Tissue-specific transcriptional activity of a pancreatic islet cell-specific enhancer sequence/Pax6-binding site determined in normal adult tissues in vivo using transgenic mice. Mol. Endocrinol. 1999, 13, 718-728. [CrossRef] [PubMed]

54. Schinner, S.; Dellas, C.; Schroder, M.; Heinlein, C.A.; Chang, C.; Fischer, J.; Knepel, W. Repression of glucagon gene transcription by peroxisome proliferator-activated receptor gamma through inhibition of Pax6 transcriptional activity. J. Biol. Chem. 2002, 277, 1941-1948. [CrossRef] [PubMed]

55. Miller, C.P.; McGehee, R.E., Jr.; Habener, J.F. IDX-1: A new homeodomain transcription factor expressed in rat pancreatic islets and duodenum that transactivates the somatostatin gene. EMBO J. 1994, 13, 1145-1156. [CrossRef] [PubMed]

56. Vallejo, M.; Miller, C.P.; Beckman, W.; Habener, J.F. Repression of somatostatin gene transcription mediated by two promoter silencer elements. Mol. Cell. Endocrinol. 1995, 113, 61-72. [CrossRef]

57. Schagdarsurengin, U.; Gimm, O.; Hoang-Vu, C.; Dralle, H.; Pfeifer, G.P.; Dammann, R. Frequent epigenetic silencing of the CpG island promoter of RASSF1A in thyroid carcinoma. Cancer Res. 2002, 62, 3698-3701. [PubMed]

58. Elisei, R.; Shiohara, M.; Koeffler, H.P.; Fagin, J.A. Genetic and epigenetic alterations of the cyclin-dependent kinase inhibitors p15INK4b and p16INK4a in human thyroid carcinoma cell lines and primary thyroid carcinomas. Cancer 1998, 83, 2185-2193. [CrossRef]

59. Bird, A.P. CpG-rich islands and the function of DNA methylation. Nature 1986, 321, 209-213. [CrossRef]

60. Jin, Z.; Mori, Y.; Hamilton, J.P.; Olaru, A.; Sato, F.; Yang, J.; Ito, T.; Kan, T.; Agarwal, R.; Meltzer, S.J. Hypermethylation of the somatostatin promoter is a common, early event in human esophageal carcinogenesis. Cancer 2008, 112, 43-49. [CrossRef]

61. Shi, X.; Li, X.; Chen, L.; Wang, C. Analysis of somatostatin receptors and somatostatin promoter methylation in human gastric cancer. Oncol. Lett. 2013, 6, 1794-1798. [CrossRef] [PubMed]

62. Leiszter, K.; Sipos, F.; Galamb, O.; Krenacs, T.; Veres, G.; Wichmann, B.; Furi, I.; Kalmar, A.; Patai, A.V.; Toth, K.; et al. Promoter hypermethylation-related reduced somatostatin production promotes uncontrolled cell proliferation in colorectal cancer. PLoS ONE 2015, 10, e0118332. [CrossRef]

63. Hoogendoorn, B.; Coleman, S.L.; Guy, C.A.; Smith, K.; Bowen, T.; Buckland, P.R.; O’Donovan, M.C. Functional analysis of human promoter polymorphisms. Hum. Mol. Genet. 2003, 12, 2249-2254. [CrossRef] [PubMed]

64. Tremblay, M.; Brisson, D.; Gaudet, D. Association between a polymorphic poly-T repeat sequence in the promoter of the somatostatin gene and hypertension. Hypertens. Res. Off. J. Jpn. Soc. Hypertens. 2016, 39, 467-474. [CrossRef] [PubMed] 
65. Zhao, L.; Wang, C.; Lehman, M.L.; He, M.; An, J.; Svingen, T.; Spiller, C.M.; Ng, E.T.; Nelson, C.C.; Koopman, P. Transcriptomic analysis of mRNA expression and alternative splicing during mouse sex determination. Mol. Cell. Endocrinol. 2018, 478, 84-96. [CrossRef]

66. Li, W.; Shi, Y.H.; Yang, R.L.; Cui, J.; Xiao, Y.; Wang, B.; Le, G.W. Effect of somatostatin analog on high-fat diet-induced metabolic syndrome: Involvement of reactive oxygen species. Peptides 2010, 31, 625-629. [CrossRef]

67. Montminy, M.R.; Bilezikjian, L.M. Binding of a nuclear protein to the cyclic-AMP response element of the somatostatin gene. Nature 1987, 328, 175-178. [CrossRef] [PubMed]

68. Andrisani, O.M.; Pot, D.A.; Zhu, Z.; Dixon, J.E. Three sequence-specific DNA-protein complexes are formed with the same promoter element essential for expression of the rat somatostatin gene. Mol. Cell Biol. 1988, 8 , 1947-1956. [CrossRef]

69. Andrisani, O.M.; Zhu, Z.N.; Pot, D.A.; Dixon, J.E. In vitro transcription directed from the somatostatin promoter is dependent upon a purified 43-kDa DNA-binding protein. Proc. Natl. Acad. Sci. USA 1989, 86, 2181-2185. [CrossRef]

70. Mantamadiotis, T.; Lemberger, T.; Bleckmann, S.C.; Kern, H.; Kretz, O.; Martin Villalba, A.; Tronche, F.; Kellendonk, C.; Gau, D.; Kapfhammer, J.; et al. Disruption of CREB function in brain leads to neurodegeneration. Nat. Genet. 2002, 31, 47-54. [CrossRef]

71. Bleckmann, S.C.; Blendy, J.A.; Rudolph, D.; Monaghan, A.P.; Schmid, W.; Schutz, G. Activating transcription factor 1 and CREB are important for cell survival during early mouse development. Mol. Cell Biol. 2002, 22, 1919-1925. [CrossRef] [PubMed]

72. Walton, K.M.; Rehfuss, R.P.; Chrivia, J.C.; Lochner, J.E.; Goodman, R.H. A dominant repressor of cyclic adenosine $3^{\prime}, 5^{\prime}$-monophosphate (cAMP)-regulated enhancer-binding protein activity inhibits the cAMP-mediated induction of the somatostatin promoter in vivo. Mol. Endocrinol. 1992, 6, 647-655.

73. Gonzalez, G.A.; Montminy, M.R. Cyclic AMP stimulates somatostatin gene transcription by phosphorylation of CREB at serine 133. Cell 1989, 6, 675-680. [CrossRef]

74. Wang, H.M.; Dong, J.H.; Li, Q.; Hu, Q.; Ning, S.L.; Zheng, W.; Cui, M.; Chen, T.S.; Xie, X.; Sun, J.P.; et al. A stress response pathway in mice upregulates somatostatin level and transcription in pancreatic delta cells through Gs and beta-arrestin 1. Diabetologia 2014, 57, 1899-1910. [CrossRef]

75. Vallejo, M.; Gosse, M.E.; Beckman, W.; Habener, J.F. Impaired cyclic AMP-dependent phosphorylation renders CREB a repressor of C/EBP-induced transcription of the somatostatin gene in an insulinoma cell line. Mol. Cell Biol. 1995, 15, 415-424. [CrossRef] [PubMed]

76. Gachon, F.; Thebault, S.; Peleraux, A.; Devaux, C.; Mesnard, J.M. Molecular interactions involved in the transactivation of the human T-cell leukemia virus type 1 promoter mediated by Tax and CREB-2 (ATF-4). Mol. Cell Biol. 2000, 20, 3470-3481. [CrossRef]

77. Marshak, S.; Benshushan, E.; Shoshkes, M.; Leibovitz, G.; Kaiser, N.; Gross, D.; Bertuzzi, F.; Cerasi, E.; Melloul, D. beta-cell-specific expression of insulin and PDX-1 genes. Diabetes 2001, 50 (Suppl. 1), S131-S132. [CrossRef]

78. Melloul, D.; Tsur, A.; Zangen, D. Pancreatic Duodenal Homeobox (PDX-1) in health and disease. J. Pediatr. Endocrinol. Metab. 2002, 15, 1461-1472. [CrossRef]

79. Piran, R.; Lee, S.H.; Li, C.R.; Charbono, A.; Bradley, L.M.; Levine, F. Pharmacological induction of pancreatic islet cell transdifferentiation: Relevance to type I diabetes. Cell Death Dis. 2014, 5, e1357. [CrossRef]

80. Leonard, J.; Peers, B.; Johnson, T.; Ferreri, K.; Lee, S.; Montminy, M.R. Characterization of somatostatin transactivating factor-1, a novel homeobox factor that stimulates somatostatin expression in pancreatic islet cells. Mol. Endocrinol. 1993, 7, 1275-1283.

81. Lu, M.; Miller, C.; Habener, J.F. Functional regions of the homeodomain protein IDX-1 required for transactivation of the rat somatostatin gene. Endocrinology 1996, 137, 2959-2967. [CrossRef]

82. Peers, B.; Sharma, S.; Johnson, T.; Kamps, M.; Montminy, M. The pancreatic islet factor STF-1 binds cooperatively with $\mathrm{Pbx}$ to a regulatory element in the somatostatin promoter: Importance of the FPWMK motif and of the homeodomain. Mol. Cell Biol. 1995, 15, 7091-7097. [CrossRef] [PubMed]

83. Goudet, G.; Delhalle, S.; Biemar, F.; Martial, J.A.; Peers, B. Functional and cooperative interactions between the homeodomain PDX1, Pbx, and Prep1 factors on the somatostatin promoter. J. Biol. Chem. 1999, 274, 4067-4073. [CrossRef] 
84. Epstein, J.A.; Glaser, T.; Cai, J.; Jepeal, L.; Walton, D.S.; Maas, R.L. Two independent and interactive DNA-binding subdomains of the Pax6 paired domain are regulated by alternative splicing. Genes Dev. 1994, 8, 2022-2034. [CrossRef]

85. Wolf, G.; Hessabi, B.; Karkour, A.; Henrion, U.; Dahlhaus, M.; Ostmann, A.; Giese, B.; Fraunholz, M.; Grabarczyk, P.; Jack, R.; et al. The activation of the rat insulin gene II by BETA2 and PDX-1 in rat insulinoma cells is repressed by Pax6. Mol. Endocrinol. 2010, 24, 2331-2342. [CrossRef]

86. Ritz-Laser, B.; Gauthier, B.R.; Estreicher, A.; Mamin, A.; Brun, T.; Ris, F.; Salmon, P.; Halban, P.A.; Trono, D.; Philippe, J. Ectopic expression of the beta-cell specific transcription factor Pdx1 inhibits glucagon gene transcription. Diabetologia 2003, 46, 810-821. [CrossRef] [PubMed]

87. Andersen, F.G.; Jensen, J.; Heller, R.S.; Petersen, H.V.; Larsson, L.I.; Madsen, O.D.; Serup, P. Pax6 and Pdx1 form a functional complex on the rat somatostatin gene upstream enhancer. FEBS Lett. 1999, 445, 315-320. [CrossRef]

88. Zhou, Y.; Sun, H.; Danila, D.C.; Johnson, S.R.; Sigai, D.P.; Zhang, X.; Klibanski, A. Truncated activin type I receptor Alk4 isoforms are dominant negative receptors inhibiting activin signaling. Mol. Endocrinol. 2000, 14, 2066-2075. [CrossRef]

89. Gongrich, C.; Krapacher, F.A.; Munguba, H.; Fernandez-Suarez, D.; Andersson, A.; Hjerling-Leffler, J.; Ibanez, C.F. ALK4 coordinates extracellular and intrinsic signals to regulate development of cortical somatostatin interneurons. J. Cell Biol. 2020, 219, e201905002. [CrossRef]

90. Munoz, W.; Tremblay, R.; Levenstein, D.; Rudy, B. Layer-specific modulation of neocortical dendritic inhibition during active wakefulness. Science 2017, 355, 954-959. [CrossRef]

91. Denaxa, M.; Kalaitzidou, M.; Garefalaki, A.; Achimastou, A.; Lasrado, R.; Maes, T.; Pachnis, V. Maturation-promoting activity of SATB1 in MGE-derived cortical interneurons. Cell Rep. 2012, 2, 1351-1362. [CrossRef] [PubMed]

92. Lee, T.I.; Young, R.A. Transcriptional regulation and its misregulation in disease. Cell 2013, 152, $1237-1251$. [CrossRef]

93. Rage, F.; Alonso, G.; Tapia-Arancibia, L. Stimulatory effect of N-methyl-D-aspartate on somatostatin gene expression in cultured hypothalamic neurons. Brain Res. Mol. Brain Res. 1993, 17, 287-294. [CrossRef]

94. Rage, F.; Rougeot, C.; Tapia-Arancibia, L. GABAA and NMDA receptor activation controls somatostatin messenger RNA expression in primary cultures of hypothalamic neurons. Neuroendocrinology 1994, 60, 470-476. [CrossRef] [PubMed]

95. Rage, F.; Jalaguier, S.; Rougeot, C.; Tapia-Arancibia, L. GABA inhibition of somatostatin gene expression in cultured hypothalamic neurones. Neuroreport 1993, 4, 320-322. [CrossRef]

96. Cammalleri, M.; Bagnoli, P.; Bigiani, A. Molecular and Cellular Mechanisms Underlying Somatostatin-Based Signaling in Two Model Neural Networks, the Retina and the Hippocampus. Int. J. Mol. Sci 2019, 20, 2506. [CrossRef]

97. Juretic, N.; Urzua, U.; Munroe, D.J.; Jaimovich, E.; Riveros, N. Differential gene expression in skeletal muscle cells after membrane depolarization. J. Cell Physiol. 2007, 210, 819-830. [CrossRef]

98. Tyssowski, K.M.; DeStefino, N.R.; Cho, J.H.; Dunn, C.J.; Poston, R.G.; Carty, C.E.; Jones, R.D.; Chang, S.M.; Romeo, P.; Wurzelmann, M.K.; et al. Different Neuronal Activity Patterns Induce Different Gene Expression Programs. Neuron 2018, 98, 530-546. [CrossRef]

99. Tolon, R.M.; Sanchez-Franco, F.; Lopez Fernandez, J.; Lorenzo, M.J.; Vazquez, G.F.; Cacicedo, L. Regulation of somatostatin gene expression by veratridine-induced depolarization in cultured fetal cerebrocortical cells. Brain Res. Mol. Brain Res. 1996, 35, 103-110. [CrossRef]

100. Tolon, R.M.; Sanchez Franco, F.; de los Frailes, M.T.; Lorenzo, M.J.; Cacicedo, L. Effect of potassium-induced depolarization on somatostatin gene expression in cultured fetal rat cerebrocortical cells. J. Neurosci. 1994, 14, 1053-1059. [CrossRef]

101. Cacicedo, L.; Tolon, R.M.; Lorenzo, M.J.; Lopez, J.; Sanchez Franco, F. Potassium-induced depolarization stimulates somatostatin gene expression in cultured fetal rat cerebrocortical cells. J. Pediatric Endocrinol. 1993, 6, 219-223. [CrossRef]

102. Sanchez-Munoz, I.; Sanchez-Franco, F.; Vallejo, M.; Fernandez, A.; Palacios, N.; Fernandez, M.; Cacicedo, L. Activity-dependent somatostatin gene expression is regulated by cAMP-dependent protein kinase and Ca2+-calmodulin kinase pathways. J. Neurosci. Res. 2010, 88, 825-836. [CrossRef] 
103. Ehrman, M.M.; Melroe, G.T.; Kittilson, J.D.; Sheridan, M.A. Glucose-stimulated somatostatin gene expression in the Brockmann bodies of rainbow trout (Oncorhynchus mykiss) results from increased mRNA transcription and not from altered mRNA stability. Zool. Sci. 2004, 21, 87-91. [CrossRef]

104. Dumonteil, E.; Magnan, C.; Ritz-Laser, B.; Ktorza, A.; Meda, P.; Philippe, J. Glucose regulates proinsulin and prosomatostatin but not proglucagon messenger ribonucleic acid levels in rat pancreatic islets. Endocrinology 2000, 141, 174-180. [CrossRef] [PubMed]

105. Ehrman, M.M.; Melroe, G.T.; Kittilson, J.D.; Sheridan, M.A. Regulation of pancreatic somatostatin gene expression by insulin and glucagon. Mol. Cell. Endocrinol. 2005, 235, 31-37. [CrossRef] [PubMed]

106. Papachristou, D.N.; Pham, K.; Zingg, H.H.; Patel, Y.C. Tissue-specific alterations in somatostatin mRNA accumulation in streptozocin-induced diabetes. Diabetes 1989, 38, 752-757. [CrossRef] [PubMed]

107. Patel, Y.C.; Cameron, D.P.; Bankier, A.; Malaisse-Lagae, F.; Ravazzola, M.; Studer, P.; Orci, L. Changes in somatostatin concentration in pancreas and other tissues of streptozotocin diabetic rats. Endocrinology 1978, 103, 917-923. [CrossRef]

108. Julien, S.; Laine, J.; Morisset, J. Regulation of rat pancreatic CCKB receptor and somatostatin expression by insulin. Diabetes 2004, 53, 1526-1534. [CrossRef]

109. Tannenbaum, G.S.; Martin, J.B.; Colle, E. Ultradian growth hormone rhythm in the rat: Effects of feeding, hyperglycemia, and insulin-induced hypoglycemia. Endocrinology 1976, 99, 720-727. [CrossRef]

110. Santiago, J.A.; Kadowitz, P.J. Analysis of responses to pituitary adenylate cyclase activating polypeptide-38 in the feline hindquarters vascular bed. Eur J. Pharm. 1993, 243, 291-294. [CrossRef]

111. Hunter, W.M.; Willoughby, J.M.; Strong, J.A. Plasma insulin and growth hormone during 22-hour fasts and after graded glucose loads in six healthy adults. J. Endocrinol. 1968, 40, 297-311. [CrossRef]

112. Roth, J.; Glick, S.M.; Yalow, R.S.; Bersonsa, S.A. Hypoglycemia: A potent stimulus to secretion of growth hormone. Science 1963, 140, 987-988. [CrossRef] [PubMed]

113. Katoh-Semba, R.; Takeuchi, I.K.; Semba, R.; Kato, K. Distribution of brain-derived neurotrophic factor in rats and its changes with development in the brain. J. Neurochem. 1997, 69, 34-42. [CrossRef] [PubMed]

114. Jin, W. Regulation of BDNF-TrkB Signaling and Potential Therapeutic Strategies for Parkinson's Disease. J. Clin. Med. 2020, 9, 257. [CrossRef]

115. Andero, R.; Choi, D.C.; Ressler, K.J. BDNF-TrkB receptor regulation of distributed adult neural plasticity, memory formation, and psychiatric disorders. Prog. Mol. Biol. Transl. Sci. 2014, 122, 169-192. [PubMed]

116. Rage, F.; Riteau, B.; Alonso, G.; Tapia-Arancibia, L. Brain-derived neurotrophic factor and neurotrophin-3 enhance somatostatin gene expression through a likely direct effect on hypothalamic somatostatin neurons. Endocrinology 1999, 140, 909-916. [CrossRef] [PubMed]

117. Sanchez-Munoz, I.; Sanchez-Franco, F.; Vallejo, M.; Fernandez, A.; Palacios, N.; Fernandez, M.; Sanchez-Grande, M.; Cacicedo, L. Regulation of somatostatin gene expression by brain derived neurotrophic factor in fetal rat cerebrocortical cells. Brain Res. 2011, 1375, 28-40. [CrossRef]

118. Spencer, T.K.; Mellado, W.; Filbin, M.T. BDNF activates CaMKIV and PKA in parallel to block MAG-mediated inhibition of neurite outgrowth. Mol. Cell. Neurosci. 2008, 38, 110-116. [CrossRef]

119. Impey, S.; Fong, A.L.; Wang, Y.; Cardinaux, J.R.; Fass, D.M.; Obrietan, K.; Wayman, G.A.; Storm, D.R.; Soderling, T.R.; Goodman, R.H. Phosphorylation of CBP mediates transcriptional activation by neural activity and CaM kinase IV. Neuron 2002, 34, 235-244. [CrossRef]

120. Villuendas, G.; Sanchez-Franco, F.; Palacios, N.; Fernandez, M.; Cacicedo, L. Involvement of VIP on BDNF-induced somatostatin gene expression in cultured fetal rat cerebral cortical cells. Brain Res. Mol. Brain Res. 2001, 94, 59-66. [CrossRef]

121. Kovac, S.; Xiao, L.; Shulkes, A.; Patel, O.; Baldwin, G.S. Gastrin increases its own synthesis in gastrointestinal cancer cells via the CCK2 receptor. FEBS Lett. 2010, 584, 4413-4418. [CrossRef] [PubMed]

122. Kim, I.; Kim, C.H.; Yim, Y.S.; Ahn, Y.S. Autocrine function of erythropoietin in IGF-1-induced erythropoietin biosynthesis. Neuroreport 2008, 19, 1699-1703. [CrossRef] [PubMed]

123. Zoja, C.; Bettoni, S.; Morigi, M.; Remuzzi, G.; Rambaldi, A. Interleukin-1 regulates cytokine gene expression in human mesangial cells through the interleukin-1 receptor type 1. J. Am. Soc. Nephrol. 1992, 2, 1709-1715. [PubMed]

124. Braun, M.; Ramracheya, R.; Rorsman, P. Autocrine regulation of insulin secretion. Diabetes Obes. Metab. 2012, 14 (Suppl. 3), 143-151. [CrossRef] [PubMed] 
125. Leibiger, B.; Moede, T.; Muhandiramlage, T.P.; Kaiser, D.; Vaca Sanchez, P.; Leibiger, I.B.; Berggren, P.O. Glucagon regulates its own synthesis by autocrine signaling. Proc. Natl. Acad. Sci. USA 2012, 109, 20925-20930. [CrossRef] [PubMed]

126. Patel, S.G.; Zhou, G.; Liu, S.H.; Li, M.; Jeong, J.W.; DeMayo, F.J.; Gingras, M.C.; Gibbs, R.A.; Fisher, W.E.; Brunicardi, F.C. Microarray analysis of somatostatin receptor 5-regulated gene expression profiles in murine pancreas. World J. Surg. 2009, 33, 630-637. [CrossRef]

127. Zatelli, M.C.; Tagliati, F.; Taylor, J.E.; Rossi, R.; Culler, M.D.; degli Uberti, E.C. Somatostatin receptor subtypes 2 and 5 differentially affect proliferation in vitro of the human medullary thyroid carcinoma cell line tt. J. Clin. Endocrinol. Metab. 2001, 86, 2161-2169. [CrossRef]

128. Zhou, G.; Liu, S.H.; Shahi, K.M.; Wang, H.; Duan, X.; Lin, X.; Feng, X.H.; Li, M.; Fisher, W.E.; Demayo, F.J.; et al. Negative regulation of pancreatic and duodenal homeobox-1 by somatostatin receptor subtype 5. Mol. Endocrinol. 2012, 26, 1225-1234. [CrossRef]

129. Jepsen, S.L.; Grunddal, K.V.; Wewer Albrechtsen, N.J.; Engelstoft, M.S.; Gabe, M.B.N.; Jensen, E.P.; Orskov, C.; Poulsen, S.S.; Rosenkilde, M.M.; Pedersen, J.; et al. Paracrine crosstalk between intestinal L- and D-cells controls secretion of glucagon-like peptide-1 in mice. Am. J. Physiol. Endocrinol. Metab. 2019, 317, E1081-E1093. [CrossRef]

130. Bos, J.L. Epac: A new cAMP target and new avenues in cAMP research. Nat. Rev. Mol. Cell Biol. 2003, 4, 733-738. [CrossRef]

131. Patel, Y.C. Somatostatin and its receptor family. Front. Neuroendocrinol. 1999, 20, 157-198. [CrossRef] [PubMed]

132. Eigler, T.; Ben-Shlomo, A.; Zhou, C.; Khalafi, R.; Ren, S.G.; Melmed, S. Constitutive somatostatin receptor subtype-3 signaling suppresses growth hormone synthesis. Mol. Endocrinol. 2014, 28, 554-564. [CrossRef]

133. Jacobs, S.; Calebiro, D.; Nikolaev, V.O.; Lohse, M.J.; Schulz, S. Real-time monitoring of somatostatin receptor-cAMP signaling in live pituitary. Endocrinology 2010, 151, 4560-4565. [CrossRef] [PubMed]

134. Feelders, R.A.; Hofland, L.J.; van Aken, M.O.; Neggers, S.J.; Lamberts, S.W.; de Herder, W.W.; van der Lely, A.J. Medical therapy of acromegaly: Efficacy and safety of somatostatin analogues. Drugs 2009, 69, 2207-2226. [CrossRef] [PubMed]

135. Patil, V.S.; Zhou, R.; Rana, T.M. Gene regulation by non-coding RNAs. Crit. Rev. Biochem. Mol. Biol. 2014, 49, 16-32. [CrossRef]

136. Tellier, M.; Maudlin, I.; Murphy, S. Transcription and splicing: A two-way street. Wiley Interdiscip. Rev. RNA 2020, e1593. [CrossRef]

137. Han, Z.J.; Feng, Y.H.; Gu, B.H.; Li, Y.M.; Chen, H. The post-translational modification, SUMOylation, and cancer (Review). Int. J. Oncol. 2018, 52, 1081-1094. [CrossRef] 